REVISTA ARA Nº. VOlUME 9. PRIMAVERA+VERÃO 2020 • GRUPO MUSEU/PATRIMÔNIO FAU-USP

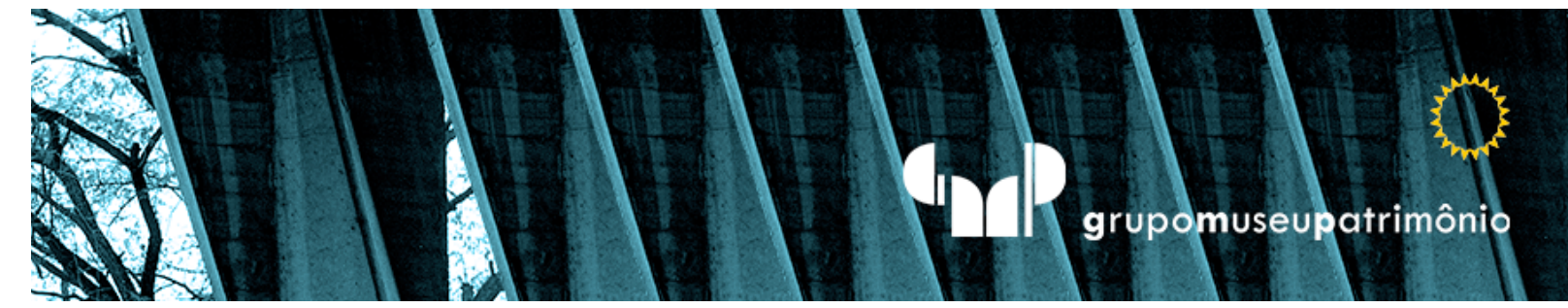

\title{
Lampejo do passado no presente
}

\author{
Destello del pasado en el presente
}

Flash of the past in the present

Maria Cecília França Lourenço

Faculdade de Arquitetura e Urbanismo/ USP. São Paulo, Brasil. mcfloure@usp.br 


\section{Resumo}

Pesquisam-se ações memoriais, fixadas em formas. Em 2016 surgiu o Memorial Cabeza de Vaca/PR e em 2020, o grafite de Mundano/SP alusivo à tragédia da Cia. Vale, em Brumadinho/MG. Como o ontem raia no hoje e rasga certezas? O que se omitiu? Quais soluções, técnica, material e poética usadas? Contra e a favor de quem se rebelam? Como se dá a reunião de recursos? Por que? Qual a diferença na abordagem da memória?

Palavras-Chave: Memória. Entre-espaço. Imagem. Política cultural. Fricção.

\section{Resumen}

Se investigan las acciones conmemorativas, fijas en sus formas. En 2016 llegó el Conmemorativo Cabeza de Vaca/PR y, en 2020, el graffiti de Mundano/SP, aludiendo a la tragedia de la Compañía Vale, Brumadinho / MG. ¿Cómo se asalta ayer las rachas de hoy y rompe las certezas? ¿Qué le dijiste a las obras? ¿Qué soluciones, técnica y material se utilizaron? ¿Contra y a favor de quién se rebelan? ¿Cómo se lleva a cabo la reunión de recursos? ¿Por qué? ¿Cuál es la diferencia en el enfoque de memoria?

Palavras-Clave: Memoria. Entre el espacio. Imagen. Política cultural. Fricción.

\section{Abstract}

Researche here memorial actions, fixed in forms. In 2016 came the Cabeza de Vaca/PR Memorial and, in 2020, Mundano's graffiti/SP alluding to the tragedy of the Company Vale, in Brumadinho / MG. How yesterday streaks in today and rips certainties? What did you say to the works? What were used solutions, technique and material? Against and for those who rebel? How does the resource meeting take place? Why is that? What is the difference in the memory approach?

Keywords: Memory. Between space. Image. Cultural politics. Friction. 


\section{INTRODUÇÃO}

Não é que o passado lança sua luz sobre o presente ou que o presente lança luz sobre o passado; mas a imagem é aquilo em que o ocorrido encontra o agora num lampejo, formando uma constelação. Em outras palavras: a imagem é a dialética na imobilidade. Pois, enquanto a relação do presente com o passado é puramente temporal, a do ocorrido com o agora é dialética; não é uma progressão e sim uma imagem que salta. Somente as imagens dialéticas são autênticas; e o lugar onde as encontramos é a linguagem (BENJAMIN, 2006, p.504).

\footnotetext{
estudo sobre Memoriais ${ }^{1}$, aqui proposto, visa interpretar episódios do passado, carregados de imagens, ora em louvor, ora em reprimenda. Cada um deles entrelaça uma tríade: razão de quem propôs, de homenageado e de criador. O resultado situa-se entre espaços, intenções, dúvidas, crises e cabe à concepção eleger momentos estelares, a valorizar o resultado. A intricada narrativa aborda esquecidos, aventuras, desastres, hecatombes, injustiça, trauma, crimes contra o humano e o meio.
}

\footnotetext{
${ }^{1}$ Investigação feita dentro do Projeto Professor Sênior na FAU USP.
} 
Impedem a captação imediata das várias partes em jogo, idealizações de personagens, ocorrências históricas e situações espoliativas, além de elogiar parcela do todo, que justifique a iniciativa e os recursos. Ademais, tal fabulação fincada em heroismo apaga temor, erro e desvio próprios do humano. A investigação tenta alargar e interpretar o passado, que ainda se faz presente e sendo nefasto esgueira-se por entre frestas e meandros.

Processos para edificar tais formas memoriais exigem acordos, abrigam-se em espaço "meio a meio", na expressão do escritor, poeta, pensador João Guimarães Rosa em a "Terceira Margem" (1994, p. 404). Como um raio vindo do passado, faíscam e iluminam para o presente certas partes abatidas, dissipadas ou definhadas. Cabe aqui revolver tais camadas, que despontam por ação de parcela sensível, ou mesmo, daquela ré pelo impacto gerado, localizando-se entre cá e lá, ou como diria Rosa, na Terceira Margem.

Walter Benjamin formula a questão de imagem dialética em que o ocorrido e o agora se deparam, por lampejo. Tal acepção aproxima-se de outro conceito central na produção do autor alemão, nomeado por aura, como se verá. 0 memorial desloca o sujeito-tema expresso por imagens para the agregar uma aura, distinta e capaz de marcar o presente, fixado entre próximo-distante.

A imagem dialética estabelece relações em dupla mão, diferente de opções como transplante e dependência cultural. O próximo-distante tem sido mote relevante na América Latina, desde o colonialismo até a atualidade. Já em 1940 o antropólogo e etnólogo cubano, Fernando Ortíz, em Contrapunteo cubano del tabaco y el azúcar (1940), introduz o termo "transculturação", em que há trocas como o tabaco cubano e o açúcar trazido, a mudar hábitos transcontinentais, até o presente. Autores latino-americanos contribuíram para estender o competente tema da transculturação.

Na derradeira passagem de século, outras reflexões surgem; cito o uruguaio Ángel Rama, em Transculturacion narrativa en América Latina (1989), ao considerar narrativas do modernismo literário, em que a vanguarda se depara 
com regionalismos, suscitando obras complexas; acrescente-se o antropólogo argentino Néstor Garcia Canclini, que alerta sobre dinâmica entre manifestações, em Culturas Híbridas, no último fim de século (1990).

Darcy Ribeiro, ao avaliar o processo de formação do povo brasileiro, desde os tupis aqui aportados antes dos portugueses e as várias transfigurações, como prefere, veio a resultar no que somos:

[...] uns latinos tardios de além-mar, amorenados na fusão com brancos e com pretos, deculturados das tradições de suas matrizes ancestrais, mas carregando sobrevivências delas que ajudam a nos contrastar [...]. (1995, p.130).

Optou-se para exame de entre lugar duas obras memorialísticas contrastantes: O "Memorial Cabeza de Vaca" (2016) tributo a Álvar Núñez Cabeza de Vaca, que seria o primeiro europeu a avistar, o que hoje se nomeia, Cataratas do Iguaçu e seus 275 saltos, como lá informam. Isto foi por ele descrito, em 1542, tendo sido guiado por nativos Guarani. Situa-se na bacia do Rio Paraná, ao lado de Puerto Iguazú /ARG e Ciudad del Este /PAR. Em 2011 foi eleita como uma das novas Sete Maravilhas da Natureza pela Fundação New Seven Wonders.

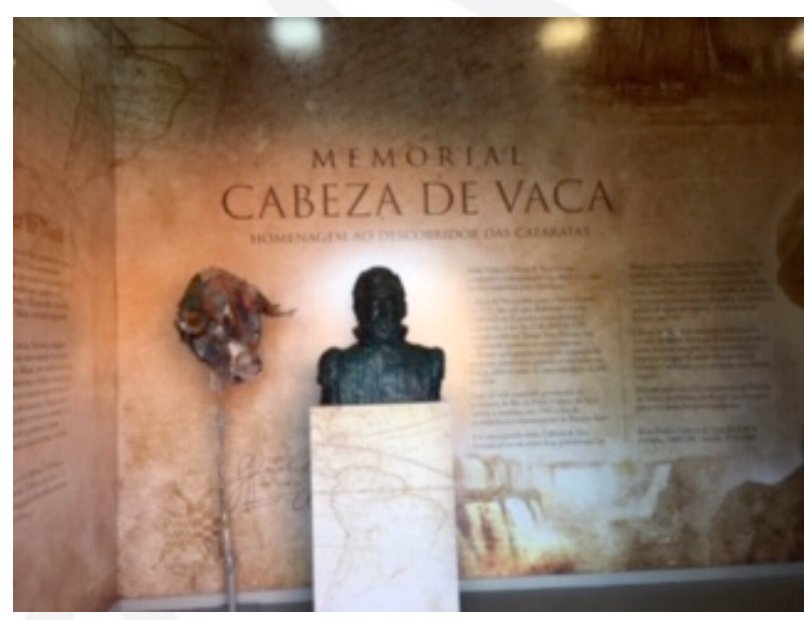

Figura 1: Entrada do Memorial Cabeza de Vaca. Foz do lguaçu/PR

Fonte: Foto A. em 26.9. 2019.

Outra obra memorialística, neste caso de um passado recente, crítica e sem toques heroicos, observa-se a em um grafite assinado por "Mundano", Thiago 
Leite $^{2}$. Ocupa empena de edifício em lugar com ampla circulação, em frente ao Mercado Central Municipal paulistano e não suaviza o libelo contra a tragédia, ao se romper a barragem da Vale do Rio Doce, em Brumadinho/MG, com sede situada na cota mais baixa. Vitimou mais de 250 pessoas, aliado ao crime ambiental devido à dissipação de rejeitos tóxicos. O grafite implantado após um ano do sinistro (25/01/2020), quando acusados não foram a júri, restam corpos não achados e a natureza expõe as chagas.

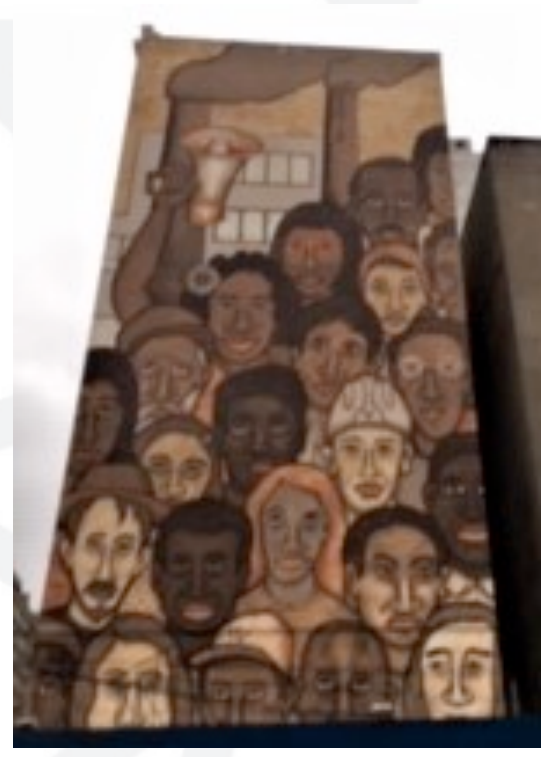

Figura 2: Mundano, “Operários de Brumadinho”. Rua Senador Queirós 667/SP Fonte: Foto A. em 03.022020.

\section{MITOS DO PRÓXIMO-DISTANTE E VICE-VERSA}

O que é teoricamente inovador e politicamente crucial é a necessidade de passar além das narrativas de subjetividades originárias e iniciais e de focalizar aqueles momentos ou processos que são produzidos na articulação de diferenças culturais. Esses 'entrelugares' fornecem o terreno para a elaboração de estratégias de subjetivação - singular ou coletiva - que dão início a novos signos de identidade e postos inovadores de colaboração e contestação, no ato de definir a própria ideia de sociedade. (BHABHA, 2001, p.20).

\footnotetext{
${ }^{2}$ Colaboraram Subtu, André Firmiano, Felipe Borges, Hélio Marques, Apcgraff e Everaldo Costa, como se veiculou na época.
} 
A operação memorialística procura gravar, no coletivo, valores distintos daqueles atuantes no presente, por vezes resvalando a personagem em mito, em outras apontando para desvios e, no oposto, evitando que a mancha se alastre para o futuro. Memorial reflete dúvida a ser aclarada, exposta ou dissipada por meio de tecido simbólico, a originar embates e ajustes.

$\mathrm{O}$ anglo indiano Homi Bhabha conceitua embates a envolver distantes por articulação de diferenças culturais em que pactos exigem deslocamentos por "[...] passagens intersticiais entre identificações [...]" (2001, p.22). Alerta-se sobre crises, surgindo espaço da intervenção "[...] nos interstícios culturais que introduz a inovação criativa dentro da existência”. (2001, p.29).

O Memorial Cabeza de Vaca data de 2016 e refere-se à figura de Álvar Núñes, espanhol, cuja aventura elucida atuação em intervalos. O tempo decorrido e a natureza do relato geram dúvidas. Para alguns nascera em Sevilha, mas, para outros, seria em Jerez de la Frontera/ESP, assim como a data, Anos 80 ou, os Anos 90 do Século XV. Narra tais proezas, assentando um entre lugar: cristão $\mathrm{x}$ xamã, divinal $x$ humano, espanhol $x$ nativo, típica situação de mito.

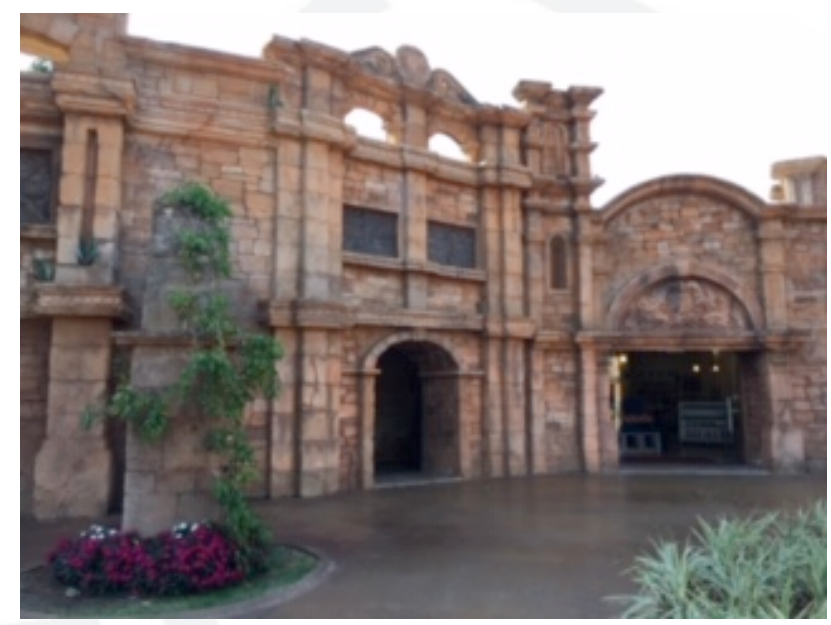

Figura 3: Entrada no Marco das Três Fronteiras. Foz do iguaçi/PR. Perfil de edificação Jesuítica. Fonte: Foto A. em 26.9. 2019.

Inserido no lado brasileiro, do Memorial se avistam Paraguai e Argentina, lembrando-se que os Rios Iguaçu e Paraná delineiam entre lugar especial, por 
ser fronteira líquida entre os referidos. De início havia um singelo obelisco em pedra, datado em 1903, em verde e amarelo, replicado nos demais com as atinentes, ou seja, o da Argentina azul e branco (1903); já o do Paraguai não há a ponta piramidal e as cores são branco, azul e vermelho, erguido nos Anos de 1960, marcos tênues para selar a amizade entre os três países.

Ditas benfeitorias atuais se deram após ser cedido à empresa privada, que no lugar de projeto optou por unir soma de partes, com fonte, luzes, espetáculos. Assim ergueu perfil edificado, a lembrar da ação jesuítica e no interior há vitrines com objetos Guarani e acolhida ao visitante. A eclosão de outras religiões, neste século, parece tangenciar e avivar aspecto protecionista de católicos com os povos originais. Grafite em pequeno sítio (2018), remissivo aos nativos, agrega Acme (Brasil), Eddy Graff (Paraguai) e Cees (Argentina).

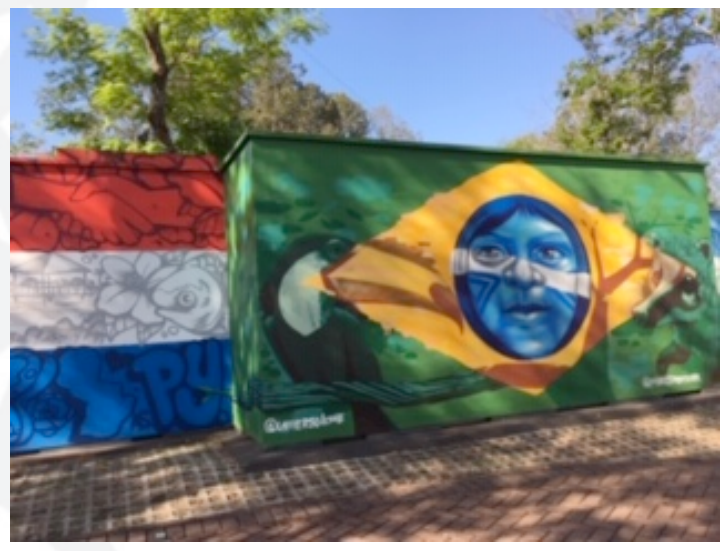

Figura 4: Grafite no Marco das Três Fronteiras.

Fonte: Foto A. em 26.9. 2019.

A hesitação em exibir o que liga as partes resulta em escala, cromatismo e enfoques díspares no Marco das Três Fronteiras/BRA. Em que pese a mistura, atrai visitantes vindos às Cataratas e leva de viajantes. Este fato se mantém desde a implantação, havendo registro da passagem da Coluna Prestes (1924) e de Marechal Cândido Rondon (1933), dado fixado em placa no local. No interior exibem trecho de filme alusivo a Núñes, e claro há loja de lembranças. 


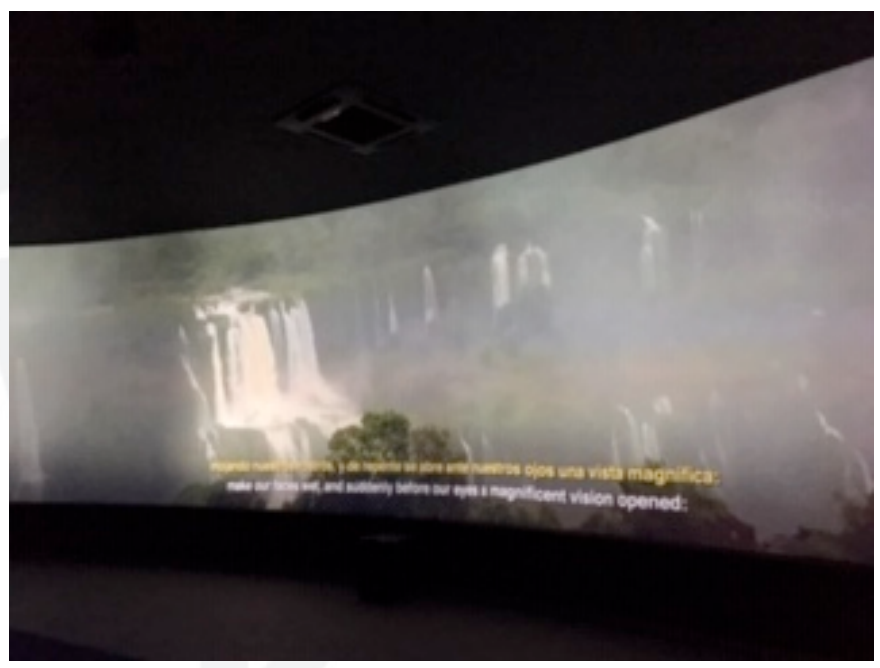

Figura 5: Projeção no Memorial Cabeza de Vaca.

Fonte: Foto A. em 26.9. 2019.

As lendas e histórias rondam Cabeza de Vaca, e biógrafos justificam este estranho aposto, como advindo da família materna. Seria de ancestral, pastor de ovelhas Martín Alhaja que, na Batalha de Navas de la Tolosa (1212), teria fincado crânio de vaca a indicar saída para cristãos em luta com muçulmanos. O combate se deu na parte sul de Madri, tendo a pista salvo as tropas de Castela, Navarra, Aragão e Portugal, que estavam sitiadas, sem provisões e armas. O rei então lhe dera o título nobiliárquico pelos préstimos.

Cabeza de Vaca memorializa as aventuras, desde que compôs a primeira caravana, a de Pánfilo de Narváez (1478-1528), que, em 17.06.1527, tomaria posse de províncias, a se estender do Rio das Palmas, atual Soto de la Marina/MEX, até o Cabo da Flórida, Texas/EUA. Núñes se achava na função de segundo comando, entre 600 membros, a incluir mulheres, além de animais, munição e 5 navios. Cabia-lhe pagar, cobrar impostos e obter provisões.

A esta expedição ele atribui o título de Naufrágios e à seguinte, que comanda e se dirige ao Sul deste Continente, Comentários, redigida depois por um escrivão, Pero Hernández. Também firma um terceiro, Rélación, algo como um Relatório, ao rei. A edição inicial aparece em Zamora, Espanha, em 1542; já as últimas, em Madrid em 1749 (MAURA, 2011, p.16). Assume tom de epopeia, 
entre lugar, entre história e ficção, entre temores e afagos. Contém traços saborosos sobre o viver nativo, natureza tropical, fauna e flora. Atrai com trechos em tom trágico, para valorizar suas ações e firmar imagem gloriosa, para habilitá-lo perante o Rei Carlos I (Imperador Carlos V).

Evita salientar a busca de ouro e prata, mas reafirma a cada momento o intento de evangelização, em visão providencialista, ao lado daquela ligada à fidelidade ao Rei espanhol. Encanta-se com paisagens e, em particular, a de Apalache no Capítulo VII, "De que manera es la terra'. Aborda rios e animais, em geral, comparando aos da Espanha. Assim, assinala a presença marcante de: [...] muy grandes árboles y montes claros, donde hay nogales y laureles y otros que se llaman liquidámbares, cedros, sabinos y encinas y pinos y robles, palmitos bajos de la manera de los de Castilla".

Menciona encontro com os originários da terra, ora hostis ora cordatos e dispostos a guiá-los, além da presença de outros europeus, também em busca de fortuna, o que desafia a versão de ser o primeiro em localizar acidentes naturais nas partes visitadas, como as atuais Cataratas do Iguaçu. Em novembro de 1528, descreve em detalhes o que dá título a seu diário, porquanto naufraga perto das Ilhas Galveston, no Texas (MAURA, 2011, p.12).

Se antes adota relação submissa ao Capitão, ou Adelantado Narváez, daí para frente o relato gira em torno de si, em forma biográfica. Ao final do Capítulo $X^{3}$ traz eventos sinistros, com suspense. Os grupos vão se dissipando, falta água e comida, restam nus e comem os próprios animais trazidos. Núñes acaba refém de nativos e obrigado a tarefas diárias, o que lhe vale a posição de prisioneiro.

As desventuras sucedem-se até o Capítulo XIII, quando o espanhol consegue travar relações com nativos e conta algo incomum. Penalizados pelo seu estado, choram e levam-no para suas casas, o que, antes the alertaram, seria perigoso. Fica por um ano, tempo de trabalho e contato com hábitos, cantos,

\footnotetext{
${ }^{3}$ Dada a quantidade de transcrições, registradas na bibliografia, a identificação das partes citadas será feita pelo número dos capítulos.
} 
relações humanas, habitação, operosidade das mulheres com lavoura, filhos e capacidade em se valer da natureza, a alterar a gravidade adotada. No Capítulo XIV registra sobre a referida tribo: "Es la gente del mundo que más aman a sus hijos y mejor tratamiento les hacen".

Fato pitoresco registra no Capítulo XXI, cujo título esclarece: "De cómo curamos aquí unos dolientes". Entre as façanhas aduz à ação com nativos a buscá-lo reclamando de dores. Como esperado, Núñes evoca a Deus por reza, benção, sopro sobre os corpos e os doentes recuperam-se. Desde então adquire a posição de curandeiro e há adesão de muitos, crendo tratar-se de um xamã, capaz de intermediar forças diversas - natureza, sacralidade, cura, ditames e mando -, reservados à dimensão divina.

Núñes em ambos registros adota duplo deslocamento, como ensina Stuart Hall. "[...] descentração dos indivíduos tanto de seu lugar no mundo social e cultural quanto de si mesmos - constitui uma 'crise de identidade' para o indivíduo" (2015, p.10). Com o passar do tempo, o explorador finca-se então em duplo deslocamento: nem cristão, nem nativo, mostrando-se sensível à diferença, que antes o assombrava. O sofrimento aproxima-o da alteridade

Cumpre adicionar que à época repercutia a pregação contra o abuso e defesa dos chamados índios, por julgar terem chegados à Índia. Ressalte-se a pregação há muito proferida pelo dominicano Frei Bartolomeu de las Casas, a ponto de Carlos I promulgar (20/11/1542) a Lei Nova, a então julgar tardiamente tais povos, como seres humanos, logo alvo de respeito, mas também dignos de servir aos negócios reais, como os demais.

Em Comentários, registrado por Hernández, em 84 capítulos, sabe-se que partiu (02/11/1540) para Buenos Aires, porém lá havia conflito e se dirigiram, em março (1541), à Ilha de Santa Catarina/BRA. Núñes fora nomeado sete meses antes, pelo rei Carlos I, Governador da Província do Rio da Prata e do Paraguai, ou Nueva Andalucia, no lugar do dirigente anterior. Embora tivesse cargo vitalício, o mandatário morrera sem deixar herdeiros e seu substituto sumira. Após reveses chega à capital, Assunção (13/03/1542). 
Ampliam-se as citações positivas relativas à cultura local, como propragava o dominicano, De las Casas, mantendo descrições sobre atritos e lutas, o papel doutrinário dos frades, clérigos, religiosos, e esforços para a conversão. Os que aderiam eram nomeados - a Serviço de Vossa Majestade. Cabe grifar outra querela religiosa dessa metade do Século XVI, a ameaçar com morte os chamados não cristãos. Sublinhe-se que desde 1478 se instalara o Tribunal do Santo Ofício da Inquisição, por Fernando II e Isabel de Castela, na Espanha, logo agindo livre de Roma e garantindo a estreita ligação - poder e Igreja.

Outro acirramento se dá em 1517, quando o padre Martinho Lutero publica suas teses reprovando o caráter mercantil da Igreja Católica ao vender perdão, as indulgências. Carlos I condena-o (1521), na Dieta de Worms. Entre 1545-63 Roma instala o Concílio de Trento, para endurecer a doutrina, a ser seguida pelos fiéis. Enquanto em Portugal conduziam os perseguidos para Lisboa, na América espanhola fixaram Tribunal Distrital para julgar em Lima (1570), Cartagena (1610) e México (1571). Esses fatores espelham-se nas repetidas vezes em que Núñes aborda pregação, evangelização, conversão, bondade e ditos nativos, capazes de se colocarem ao serviço dos Reis.

A par dessa prestação de contas, a revelar o temor aos fatos religiosos correntes, Cabeza de Vaca traz dados etnográficos significativos sobre os povos nativos por ele chamados em naturais daquela terra e ao líder, principal. Seleciona dados atributos, a citar Paiaguo habitantes do Rio Paraguai e canoeiros que mataram cristãos; Chameses, situados ao sudeste de Santa Cruz de la Sierra/Bolívia, bons para transportar carga; Carios, ou Carijós, amigos dos europeus, a ocupar desde Cananéia/SP, até Lagoa dos Patos/RS e cordilheira andina; Agaces, estabelecidos na bacia do Rio Paraguai, temidos e aos quais reserva adjetivos, desde gigantes, combativos, valentes e guerreiros, até corsários, ladrões, assaltantes e traidores, pois, após celebrar a paz, atacam, em especial os nativos, como diz sofrer a generacion Guarani.

A etnia Guarani estendeu-se por Bolívia, Paraguai, Argentina, Uruguai e no país, a região litorânea do Sul e Sudeste, além da Bacia do Rio Paraná e Prata. 
Aos poucos são alvo de elogios e, a partir do Capítulo XXVII, nomeia-os como vassalos de Vossa Majestade, convertidos e, desde o XLIV, amigos, dado habitar extenso território por ele percorrido, Núñes bem os documenta, de modo a frisar trato generoso e acolhedor.

Entre os informes, especifica: coletores, agricultores e caçadores plantam milho duas vezes ao ano; criam papagaios, além de patos e galinhas, perseguem animais, pescam; na aldeia há porcos, macacos, cachorros, veados e gatos [VIII], mas alguns se aterrorizavam com cavalos [X]. No LXIV registra a presença de espantosas formigas vermelhas e morcegos, prendendo-se galinhas à noite para não serem atacadas.

Com mesmo estilo relata que comem carne humana [VI] e, se no início chamaos de bárbaros, neste episódio assume o fato como mero informe. Nas demais partes da narrativa estende a distinção, sempre reiterando serem gentis, alegres, afáveis e alude ao escambo: trocam presentes por frutas, cana, mel, batata, mandioca, amendoim e farinha. Explana que fazem farinha com pinhões típicos da costa, sendo largas as árvores destes e propícias para fazer barcos. Aborda ritos de passagem, como maturidade e morte, descreve armas e combates, em quadro cultural minucioso.

Núñes informa sobre outros grupos ${ }^{4}$, nesse longo percurso; ele descreve no Capítulo XI as Cataratas, seu impacto e as ressalvas para sair das canoas ao avistar as Sete Quedas do Rio Iguaçu, como reza a tradição, como o primeiro europeu, embora citasse vários lá em expedições:

E yendo pelo dicho río de Iguazu abajo la corriente de él era tan grande que corrían las canoas por él con mucha fúria; y esto causólo que muy cerca de onde se embarcó dá el rio un salto de muchas peñas abajo muy altas, y da

\footnotetext{
${ }^{4}$ Guaicuru [Mato Grosso do Sul, Goiás e no Paraguai], Merchire [costa do Rio Paraguai], Naperu, Imperu e Aperu, [(possivelmente mesmo grupo acentado no Rio Paraguai); Maiae [sul do México e América Central], Sacosis, Socisies, Socoxis, Socorino, Xaquete, Xaraie [oeste do Paraguai e sul da Bolívia], Guaxarapo [alto Paraguai], Guazani e Tabere, Tarapecoci, Guató [1543/Pantanal MS, MT e Sul da Bolívia], Carcara, Chanes (também chamados Guanás, situados no território sulamericano), Arrianicosi, Artanese .
} 
el aqua en bajo de la tierra tan grande golpe, que de muy lejos se oie; y la espuma del agua como cae con tanta fuerza, sube en alto dos lanzas o más, por manera que fue necesario salir de las canoas e sacallas del agua y llevalas por tierra hasta pasar el salto y a la fuerza de brazos las llevaran más de media legua [...]. Álvar Núñes Cabeza de Vaca.

Assume tom de ode à diferença sobre o viver distinto dos nativos, natureza tropical, fauna, flora, animais, além de dramático e trágico, próximo ao sublime ante a singularidade da tal experiência. Constituem fatores decisivos para a produção considerável de títulos sobre Álvar Núñes, cuja base principal se encontra nos próprios relatos assombrosos, que bem traça, havendo reiteração por inúmeros biógrafos.

\section{AMÉRICA LATINA: TRANSCULTURAÇÃO}

[...] a memória coletiva não é uma memória, mas um discurso que evolui no espaço público. Esse discurso reflete a imagem que uma sociedade ou grupo dentro da sociedade querem dar a si mesmo (TODOROV, 2002, p. 151).

Note-se que América Latina, enquanto entre lugar, surge e se fortalece com o colonialismo permeado por embates no espaço territorial e cultural de quem vem e a civilização nativa. Ninguém fica alojado em sua cultura, sucedendo-se mesclas multidirecionais. Ilustram bem os acordos celebrados, os usuais deslocamentos e a interação entre espanhóis, jesuítas e nativos. Vivenciam memórias individuais em embate, narradas pelos dois primeiros, acarretando negociação, pois, cada parte está mergulhada naquela coletiva e, como indica Tzvetan Todorov, sobre a posição de Núñes, gravitando entre os três grupos.

O universo mental de Cabeza de Vaca parece vacilar aqui, a incerteza quanto aos referentes de seus pronomes [...], já não há dois partidos nós (os cristãos) e eles (os nativos), mas três os cristãos, os nativos e 'nós'. Mas quem são esses 'nós', exteriores a ambos [...]? (TODOROV, 1988, p.197).

O que está em jogo é subverter a visão de que na América Latina a dita civilização se transplanta, vinda de centros tidos como avançados. Para muitos a cultura local submete-se, subalterna-se, acultura-se e apenas transpõe modelos forâneos. Entre nós, o estudo do trânsito dinâmico em dupla direção 
aparece em muitos autores, como Milton Santos, Silviano Santiago, Renato Ortiz e Darcy Ribeiro, atentos a tal multidirecionalidade, a fomentar reconfiguração de valores para múltiplas culturas e áreas.

Adicione-se que o próprio discurso histórico se torna um entre tempos, vale dizer entre o passado e as inúmeras narrativas de quem conta no presente, cada um questionando ângulos, de seu interesse. Cabe sempre perguntar: por que e contra que cenário atuam? O colonialismo europeu, desde o final dos Quinhentos, bem documenta mitos e lendas, quando se cotejam com o outro, operando inúmeros dialetos, hábitos, formas, cores e sacralidade, fatores estes somados às várias subjetividades no relato do ocorrido.

Por que então tantas ações memoriais neste século e em formas variadas? Faltam lendas e heróis ao imaginário local, perdidos na mundialização cultural? A globalização impôs padrões exógenos, no dia-a-dia, dissipando valores locais? Religião, nobreza e guerras eclipsaram, exigindo-se a construção de novos ídolos? Ou apenas se revê o colonialismo, firmado no tal papel civilizatório? Almeja-se dourar as origens, para justificar a adoção de hábitos de classes privilegiadas? Evita-se disfarçar desastres? Ou pesadelos espantam sonhos e desfazem mitos a cada nova campanha para erguê-los?

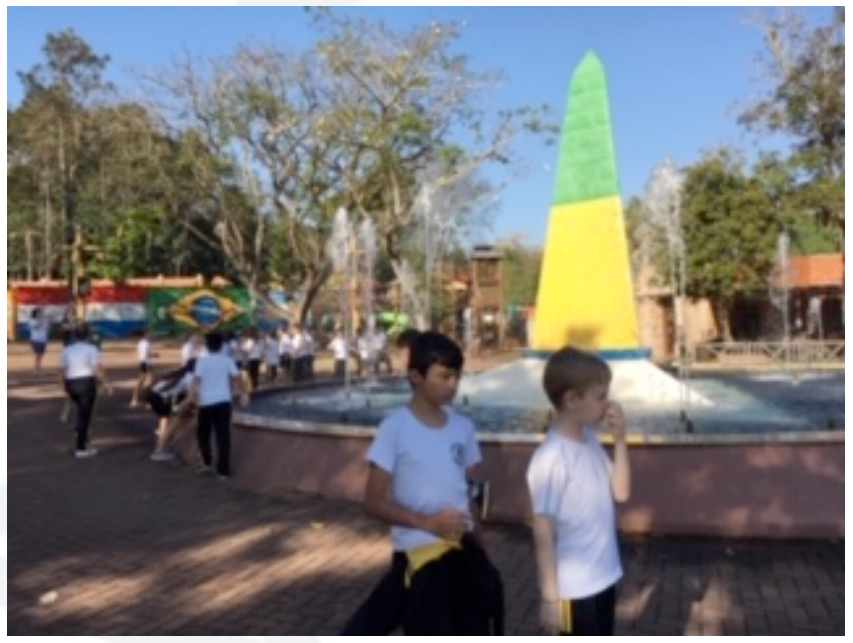

Figura 6: Obelisco no Marco das Três Fronteiras.

Fonte: Foto A. em 26.9. 2019. 
O conceito de algo na condição de entre lugar conquista relevo e, no país, sobressai-se na crítica cultural, em diálogo com outros pensadores também deslocados. Entre estes realço Silviano Santiago, em estudo sobre a Década de Ditaduras na América Latina, no clássico livro "Uma literatura nos trópicos" (1979) e reafirmou em entrevista:

Entre o sacrifício e o jogo, entre a prisão e a transgressão, entre a submissão ao código e a agressão, entre a obediência e a rebelião, entre a assimilação e a expressão, - ali, nesse lugar aparentemente vazio, seu templo e seu lugar de clandestinidade, ali, se realizam o ritual antropofágico da literatura latino-americana [e de qualquer outra nação]. (2000, p.28).

Outro subsídio fundante para matizar o que se passa no entre lugar latinoamericano se observa em Renato Ortiz, que distingue cultura e finança, evitando avaliar aquela, como mero transplante cultural, que desconsidera transmutação operada por materialidade local e poética humana. Ortiz diferencia cultura mundializada e globalização, pois nesta domina o mercado, por meio de entre lugar ao se referir, ao último fim-de-século: "Nossa contemporaneidade faz do próximo o distante, separando-nos daquilo que nos cerca, ao nos avizinhar dos lugares remotos" (1994, p.220).

Núñes e tantos outros zarparam para viagens sobre pretérito território, como se fosse espaço nulo e vazio, apesar de os povos nele fixados constituírem cultura humana singular, distinta e única no trato entre pessoas e com a natureza. Em nome de civilizá-los e convertê-los à lógica cristã, ignoraram-se hábitos, expressões, relações, habitações, fazeres e domínio sobre a tipicidade tropical. A variedade formada no espaço e a ação humana foram desprezadas.

Como bem alerta Milton Santos - "A configuração territorial não é o espaço, já que sua realidade vem de sua materialidade, enquanto o espaço reúne a materialidade e a vida que a anima". (1996, p.51). Acrescentem-se outras distinções, porquanto há diversidade em marcadores temporais para plantação, colheita, reprodução humana, sacralidade, vida e morte, a acarretar variadas divisões de trabalho, em um viver coletivizado. Como sublinha Santos: 
“(...) cada divisão do trabalho cria um tempo seu próprio, diferente do tempo anterior" (1996, p.109). O tempo de ansiedade por riqueza e domínio longe estava da métrica adotada pelos povos nativos.

Por outro lado, a hierarquia entre as funções por gênero, poder e hereditariedade se operava nos povos originais pela oralidade, grave problema para diálogo, o que levou jesuítas a se dedicar a versões e traduções, visando facilitar a doutrinação pretendida. Segundo o geógrafo, refaz-se a história, ante os conflitos, uma vez que o espaço abriga conjunto "[...] indissociável, solidário e, também, contraditório, de sistemas de objetos e sistemas de ações, não considerados isoladamente, mas como quadro único no qual a história se dá" (SANTOS, 1996, p. 63).

O referido - próximo distante - observa-se no relato de Álvar Nuñes, porquanto o chamado Tratado de Tordesilhas (1494), assinado pelos Reinos de Castela e Portugal, propunha-se a dividir um território incógnito, até por cosmógrafos, que divergiam sobre a extensão, localização, desenho e unificação da medida. Pressupunha as terras conquistadas por cada Reino, mas também aquelas que viriam a ser encontradas, sem noção de quantos e quais habitantes.

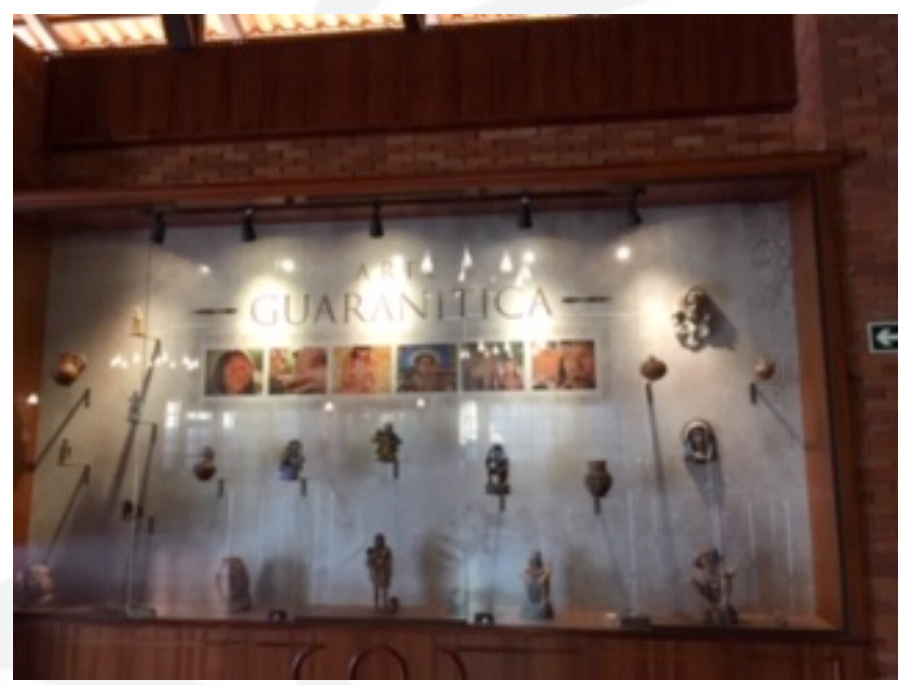

Figura 7: Vitrine com objetos Guarani. Marco das Três Fronteiras.

Fonte: Foto A. em 26.9. 2019. 
Estes somavam numerosas etnias e Darcy Ribeiro estima que no século XVI totalizavam 5 milhões de nativos $(1995$, p.143). No dizer deste, opera-se outro entre, pois várias origens se permutam. 0 resultado desse encontro multi étnico e em condição social desigual faz surgir um povo oriundo da "[...] confluência do entrechoque e do caldeamento do invasor português com nativos silvícolas e campineiros e com negros africanos, uns e outros aliciados como escravos" (1995, p.19).

\section{MEMORIAL E FRICÇÃo}

Sabemos hoje que as identidades culturais não são rígidas nem, muito menos, imutáveis. São resultados sempre transitórios e fugazes de processos de identificação. Mesmo as identidades mais sólidas, como a de mulher, homem, país africano, país latino-americano ou país europeu, escondem negociações de sentido, jogos de polissemia, choques de temporalidades em constante processo de transformação, responsáveis em última instância pela sucessão de configurações hermenêuticas que de época para época dão corpo e vida a tais identidades. Identidades são, pois, identificações em curso (SOUZA SANTOS, 2010, p.135).

A aura de memoriais em geral volta-se a hiatos pouco registrados e/ou debatidos, como o de Cabeza de Vaca, ausente dos manuais. Não raro pouca ou nenhuma fricção traz, por conceder qualificativos caros à encomenda, a exigir imagem ideada. Diferentemente de contratos, douramento e espetacularidade, o artivista grafiteiro Mundano trará as ausências, relendo a tela "Operários" (1933) de Tarsila do Amaral. Nesta há mais de cinquenta personagens, com muitas mulheres, tendo Mário de Andrade no centro. 


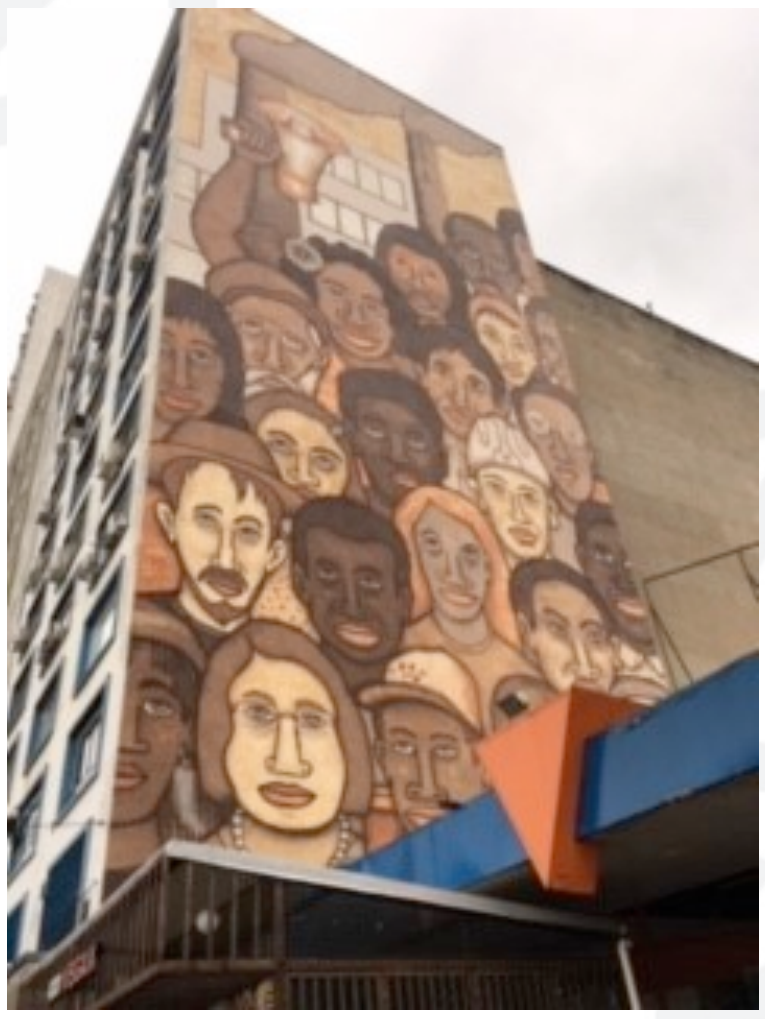

Figura 8: Mundano, “Operários de Brumadinho”. Fonte: Foto A. em 03.022020.

O artvista em "Operários de Brumadinho" reduz a 22 personagens, mantém mulheres e troca o céu azul, por tons terrosos e, à esquerda, ressalta um imenso megafone para ampliar a voz dos emudecidos. Permanecem as chaminés e os rostos-tipo, inspirados em ato realizado na Assembleia Legislativa daquela cidade mineira com fotos das vítimas, encimadas pela frase "Vale Assassina", conforme documenta em suas redes. Antes desenvolveu na capital paulista ação em 280 carroças, apontando para o excesso de lixo, urgência em reciclar e cuidado com o meio ambiente, também grafite crítico em várias cidades, nomeado "Paporreto". 


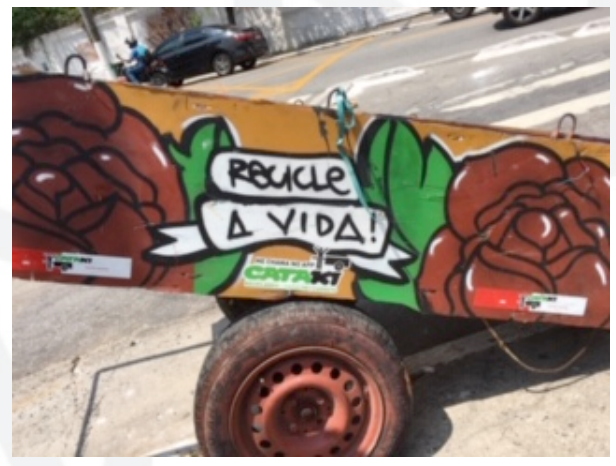

Figura 9: Mundano, Projeto "Pimp my carroça". Vila Madalena/SP.

Fonte: Foto A. em 12.03.2020

Empreende uma transcultutação narrativa, com a preocupação social da modernista, dialogando em fricção e nenhuma concessão com o ocorrido. Veja-se o uso de várias etnias, índios, brancos, negros, orientais e a palavra "Justiça" em uma das chaminés, repetida em atos nesta e em outras tragédias. Sublinhe-se o material usado e retirado daquele local, para base pictórica, alusivo à ruína de vidas, rios e plantações. O símbolo da Companhia Vale em capacete na primeira fila alteia-se e cita a realidade longínquo-próxima de Benjamin. Como se nota nestas memórias, ao contrário daquelas de Núñes, não se busca gentileza a todos, ou se usam motivos alegres, afáveis e, no lugar de escambo, clama-se por justiça.

Vale recordar conceitos de Benjamin sobre tais lampejos, no entre-guerras por vezes unindo-os à aura. Em "Pequena história da fotografia" (1931) conceituaa por meios espaciais e temporais, sendo "[...] a aparição única de uma coisa distante, por mais próxima que esteja." (1987, p. 101). Após cinco anos (1936), em plena Guerra, retoma o tema e na segunda versão alemã de "A obra de arte na época de suas técnicas de reprodução", esclarece com cena de paisagem vista em fim de tarde, tendo a sombra surgida no olhar do espectador, assim valorizando a recepção. Define-a como um entre: “[...] uma realidade longínqua, por mais próxima que esteja" (1975, p.15).

Mundano traça momento da História com imagens deslocadas que guardam potencial de lampejo, ainda quando prestes a ser obliterada. Tempo este ainda 
em curso, no entanto arregala os olhos do transeunte para tal tragédia. Não se intimidou e enviou o projeto para obtenção de recursos ao edital da Prefeitura paulistana, juntamente com a Secretaria da Cultura, a de Educação e ligada ao Museu de Arte de Rua, sendo classificado em dezembro de 2019.

O imenso grafite paulistano, em área de $205 \times 150 \mathrm{~m}^{2}$, também ressoou em mídias tecnológicas, jornais, revistas, rádio e TV, em data de feriados, em que se dedicam ao trivial. 0 artivista não deixa indiferente o espectador, ao contrário, arregala-lhe, franze-lhe a feição e exige altear a cabeça para encarar a tragédia. A criação-manifesto berra, por formas, material e cores.

Presentifica por meio de imagens a repulsa e alerta para os destroços ao verter a Mina do Córrego do Feijão, em Brumadinho/ MG. Nada se alterou, neste início de ano (2020) e a Vale insiste em pagar anúncio em horário nobre e alto custo, talvez com a pretensão de celebrar acordos coletivos, no lugar de gastar com os lesados, vã finalidade para evitar ações na Justiça.

Walter Benjamin, durante a II Guerra Mundial, vive em tempo eivado também por absurdos e temores. Define a História com base na gravura Angelus Novus (1920), de Paul Klee e de forma desusada, a saber, um anjo, com olhos escancarados, boca dilatada, asas abertas e rosto virado para o passado "[...] Onde nós vemos uma cadeia de acontecimentos, ele vê uma catástrofe única, que acumula incansavelmente ruína sobre ruína e as dispersa sobre nossos pés", no ensaio "Sobre o conceito da história" (1987, p.226).

Ausência habitual de memória e decorrer temporal parecem ser a aposta dos envolvidos nas tragédias, para acomodação de parentes, público e ressuscitar a natureza, desprezando dor e perda irreparável. Atuações com intento assistencialista tentam ser gravadas nas mentes, não sendo surpresa se anunciarem criações de memorial. Ou como diria Milton Santos, sobre fixos $e$ fluxos, aqui uma vez erguido um memorial, seriam fixos, neste caso institucional, tentando gerar fluxo benevolentes entre humanos. 
Santos alerta sobre a condição de interpenetração entre fixos e fluxos. Aquele constitui objeto material natural ou proveniente de interferência humana, que se alterou. Já os fluxos

[...] são um resultado direto ou indireto das ações e atravessam ou se instalam nos fixos, modificando a sua significação e o seu valor, ao mesmo tempo em que, também, se modifica. (2008, p.62).

No entanto, para além de assombro, o grafiteiro Mundano, habituado a ações surpreendentes, deslocou-se de São Paulo para a cena da tragédia. Assistiu a homenagens às vítimas e recolheu material tóxico bruto para produzir pigmentação utilizada na empena. As fotos fixadas no evento rememorativo foram decisivas para recuperar identidades e associá-las com cultura pictórica em evidência, a saber, obra da modernista Tarsila do Amaral.

\section{CONCLUSÃO}

Projeto ligado à memória revê resíduos camuflados em dado tempo e território e ao se efetivar, firmam-se noções em nome de ausentes e/ou evento no ontem ou no passado. Fundam relato, indício e baseiam-se em cultura material, que pode ser decifrada. Há que se inquirir: quais rumos atuais e que ações memorialísticas desejam sublinhar? Objetos e práticas em memorial expressam rastros, bons para revirar certezas, causar nova identidade e romper com a ilusão de que existe contínuo temporal histórico.

Acontecimentos incomuns e absurdos a envolver natureza pré-existente e seres biológicos em variado espectro estimulam a implantação de memoriais e marcos visuais monumentais no espaço urbano. Coincidem na intenção de abranger o todo societário, mesmo que não diretamente envolvido.

Recorta-se fração do passado para ser reescrito e, neste estudo, buscou-se investigar o porquê em dois contrastantes entre tantos erigidos neste tempo. Constituem entre lugar, afagam certa aura, agem em espaço intersticial, com deslocamentos, em que se constatam sinuosidades e veios, antes em aparente invisibilidade, ou mesmo em oposição às situações do momento. 
Ao se tratar de trincas, crises e eventos súbitos, naturais ou não, para coletividades, comuns em território ocupado ou na rotina de populações, evidencia-se duplo deslocamento, ou seja, o do lugar individual e o ocupado na constelação sociocultural, ambos consolidados, estáveis e transmitidos por gerações, sendo o memorial parte ativa no registro de imagens $e$ deslocamentos, podendo colaborar para submergir interditos.

O Memorial ocupa entre lugares, tendo em vista oscilar em meio a afrontar $\mathrm{x}$ retratar, aclararar $\mathrm{x}$ obscurescer; falar $\mathrm{x}$ esbravejar, elogiar $\mathrm{x}$ desprezar, fugir $\mathrm{x}$ enfrentar realidade perversa. Ainda que em obra individual, mas consensual para dada situação, em geral desafia o senso comum e requer múltipla análise. Aflora solução entre lugares, seja na poética e matéria, seja em conteúdo, este entre releitura do passado $\mathrm{x}$ choque do presente, idealismo $\mathrm{x}$ realismo, concisão $\mathrm{x}$ profusão, falar $\mathrm{x}$ calar, mortos $\mathrm{x}$ vivos, dor $\mathrm{x}$ glória, desprezo $\mathrm{x}$ indignação manifesta, guerra x paz.

Acrescente-se que tais embates, ao serem assentados em formas no espaço urbano, expõem analogias no trato da memória social, que se intenta reverter e firmar. Não raro, busca-se o exótico para garantir a atenção de visitante e incide-se na tônica de implantar dados na história, evitar oblívio, rever fratura, disputa territorial, política e financeira. Memorial se utilizar friç̧ão, apontará para fruidor atento transação não revelada entre partes, daí prevalecer opção por formas incisivas, materiais e técnicas atuais, a incluir escala incomum e busca pelo monumentalidade. Não basta olhar formas, há que se elaborar arqueologia das camadas encobertas propositalmente. Ciça, Verão 2020.

\section{REFERÊNCIAS BIBLIOGRÁFICAS E OUTRAS}

BENJAMIN, Walter. Sobre o conceito de História In: Magia e Técnica, Arte e Política: ensaios sobre literatura e história da cultura. 3 ed. São Paulo: Brasiliense; 1987. Obras Escolhidas v. 1.

A obra de arte na época de suas técnicas de reprodução. In: Textos escolhidos. São Paulo: Abril Cultura; 1975. 
Passagens. Tradução e coordenação: Willy Bolle. São Paulo: Imprensa Oficial do Estado/ UFMG; 2006.

Rua de mão única: Obras escolhidas, v. 2. São Paulo: Brasiliense; 1987.

GARCIA CANCLINI, Néstor. Culturas Híbridas: estratégias para entrar e sair da modernidade. São Paulo: EDUSP; 1997 [1990].

HALL, Stuart. A identidade cultural na pós-modernidade, 12 ed. Tradução Tomaz Tadeu da Silva, Guacira Lopes Louro. Rio de Janeiro: Lamparina; 2015.

HISTORIADORES primitivos de las Índias Occidentales. Tomo I. Madrid 1749. Disponível em https://www.wdl.org/es/item/162/view/1/1/ Acesso em 15.01.2020.

NÚÑES, Álvar Cabeza de Vaca. Comentários Disponível em: http://www.biblioteca-antologica.org/es/wpcontent/uploads/2017/05/CABEZA-DE-VACA-Comentarios.pdf/ Acesso em 20.02.2020

Comentários. Disponível em: https://www.wdl.org/pt/item/162/\#regions=latin-america-and-thecaribbean Acesso em 12. 01.2010.

Naufrágios. Disponível em www.elaleph.com/ http://www.educ.ar/ Acessado em 20.01.2020.Domínio Público e utilizado para as citações http://www.dominiopublico.gov.br/download/texto/ag000009.pdf , Naufrágios. Ed. Juan Francisco Maura. Madrid: Cátedra; 2006. , Naufrágios e Comentários. Trad. Jurandir Soares dos Santos. Prefácio de Henry Miller. Introdução de Eduardo Bueno. Porto Alegre: L\&PM; 1999.

Naufragios y Comentarios. Ed. Vicente Muñoz Puelles. Madrid: Anaya; 1992.

ORTÍZ, Fernando. Contrapunteo cubano del tabaco y el azúcar. Caracas, Venezuela: Biblioteca Ayacucho; 1987.

ORTIZ, Renato. Mundialização e cultura. São Paulo: Brasiliense; 1994.

RAMA, Ángel. Transculturación narrativa en América Latina. Montevideo: Fundación Ángel Rama; 1982.

RIBEIRO, Darcy. O povo brasileiro: a formação e o sentido do Brasil. São Paulo: Cia. das Letras; 1995.

ROSA, João Guimarães. "A terceira margem do rio". In: Fiç̧ão completa: volume II. Rio de Janeiro: Nova Aguilar, 1994, p. 409-13. 
Disponível em

https://www.aedi.ufpa.br/parfor/letras/images/documentos/ativ-a-distjan-fev2014/CASTANHAL/castanhal-2010-010/guimaraes\%20rosa\%20\%20a_terceira_margem_do_rio-3.pdf/ Acesso em 21. 02.2020.

SANTOS, Milton. A natureza do espaço: técnica e tempo, razão e emoção. São Paulo: Hucitec; 1996.

O espaço dividido: os dois circuitos da economia urbana dos países subdesenvolvidos. São Paulo: EDUSP; 2008.

SANTIAGO, Silviano. Uma literatura nos trópicos: ensaios sobre dependência cultural, 2 ed. Rio de Janeiro: Rocco; 2000.

SOUZA SANTOS, Boaventura de. Pela mão de Alice: o social e o político na pósmodernidade. São Paulo: Cortez; 2010.

TODOROV, Tzvtan. A conquista da América: a questão do outro. 2 ed. São Paulo: Martins Fontes; 1988.

\section{Fontes eletrônicas e sites}

MARCO das Três Fronteiras. Disponível em https://marcodastresfronteiras.com.br/ Acesso em 12.02.2019.

MUNDANO. Disponível em: https://www.instagram.com/mundano_sp/?utm_source=ig_embed\#re/ Acesso em 20.03.2020 , \#releiturasmundanas

\section{Lista de fotos}

Figura 1: Entrada do Memorial Cabeza de Vaca. Foto A. pág.: 177

Figura 2: Mundano, “Operários de Brumadinho”. Foto A. pág.: 178

Figura 3: Entrada do Marco das Três Fronteiras. Foto A. pág.: 179

Figura 4: Grafite no Marco das Três Fronteiras. Foto A. pág.: 180

Figura 5: Interior do Memorial Cabeza de Vaca. Foto A. pág.: 181

Figura 6: Grafite no Marco das Três Fronteiras. Foto A. pág.: 187

Figura 7: Vitrine com objetos Guarani. Foto A. pág.: 189

Figura 8: Mundano. “Operários de Brumadinho”. Foto A. pág.: 191

Figura 9. Mundano. Projeto "Pimp my carroça". Foto A. pág.: 192 